\title{
The Effects of Inhaled Drug Use on Saliva and Dental Plaque in Children
}

\author{
Sema Celenk (Corresponding author) \\ Department of Pediatric Dentistry, Faculty of Dentistry, Dicle University, Diyarbakir/Turkey \\ E-mail: semacelenk@gmail.com \\ Ezgi Eroglu \\ Gazi Yasargil Training and Research Hospital, Diyarbakir/Turkey \\ E-mail: ezgi.e@hotmail.com
}

\begin{abstract}
Aim: Develop awareness about the effects of inhaled drugs on saliva and dental plaque and to take precautions against these side effects. Material and Method: Our work is planned prospectively, a total of 48 children aged between 4 and 16 years were enrolled in the study. Salivary flow rate, saliva $\mathrm{pH}$, saliva buffering capacity, saliva viscosity, presence of plaque differences between the study groups and the control group were investigated. The working group is divided into 3 for standardization. Results: It was found that unstimulated salivary flow rate $(\mathrm{p}=0,2376)$, saliva viscosity $(\mathrm{p}=0.3675)$ was not directly influenced by inhaler drug use. In contrast, inhaler drug use may decrease stimulated salivary flow rate $(\mathrm{p}=0.0198)$, salivary $\mathrm{pH}(\mathrm{p}<0.0001)$, saliva buffering capacity $(\mathrm{p}$ $=0.028)$. Inhaler drug use increases dental plaque accumulation $(\mathrm{p}=0.0048)$. Conclusion: Many parameters such as stimulated salivary flow rate, saliva $\mathrm{pH}$, saliva buffering capacity and plaque quantity have been found to be influenced by inhaler drugs.
\end{abstract}

Key Words: Inhaler drug, Asthma, Salivary flow rate, Saliva buffering capacity.

DOI: $10.7176 / \mathrm{JSTR} / 5-3-10$

\section{Çocuklarda İnhaler İlaç Kullanımının Tükürük ve Dental Plak Üzerine Etkisi}

\begin{abstract}
Özet
Amaç: İnhaler ilaçların tükürük ve dental plak üzerine etkilerinin ortaya konulması ve bu yan etkilere karşı önlem alınması için gerekli farkındalığı oluşturmaktır. Gereç ve Yöntem: Çalışmamız prospektif olarak planlanıp, yaşları 4-16 arasında değişen toplam 48 çocuk hastayla yapılmıştır. Çalışma grupları ve kontrol grubu arasında tükürük akış hızı, tükürük pH' s1, tükürük tamponlama kapasitesi, tükürük viskozitesi, plak miktarı farklılıkları araştırılmıştır. Çalışma grubu standardizasyonu sağlamak için 3'e ayrılmıştır. Bulgular: Uyarılmamış tükürük akış hızının ( $\mathrm{p}=0,2376)$, tükürük viskozitesinin $(\mathrm{p}=0,3675)$ inhaler ilaç kullanımından direkt etkilenmediği tespit edilmiştir. Buna karşın inhaler ilaç kullanımı uyarılmış tükürük akış hızını( $\mathrm{p}=0,0198)$, tükürük pH'sını( $\mathrm{p}<0,0001)$, tükürük tamponlama kapasitesini $(\mathrm{p}=0,028)$ düşürebilmektedir. İnhaler ilaç kullanımının plak birikim miktarını $(\mathrm{p}=0,0048)$ arttırdığı görülmüştür. Sonuç: İnhaler ilaç kullanan çocukların uyarılmış tükürük akış hızı, tükürük pH'sı, tükürük tamponlama kapasitesi ve plak miktarı gibi pek çok parametrenin inhaler ilaç kullanımından etkilendiği tespit edilmiştir.
\end{abstract}

Anahtar Sözcükler: İnhaler ilaç, Astım, Tükürük akış hızı, Tükürük tamponlama kapasitesi 


\section{Giris}

İnhaler ilaçlar sıvı, toz ya da buhar formundaki pek çok ilacın solunum yollarına verilmesini kolaylaştııı $(1,2)$. Bu ilaçlar nebülizer, ölçülü doz inhaler (ÖDİ) ya da kuru toz inhaler (KTİ) olarak tercih edilebilir. Astım, kistik fibrozis (KF), tip 2 diyabet, bronşiyolit gibi pek çok hastalıkta inhaler tedavi kullanımı mevcuttur (2). İnhaler ilaçlar direkt, hızlı, uzun etkiye sahip olmaları, enjeksiyon sebebiyle oluşan ağrıya yol açmamaları ve yan etkilerinin minumum olması gibi önemli avantajlarından dolayı tercih edilmektedirler $(1,2)$.

İnhaler ilaçların en sık kullanıldığı hastalık astım ve en sık kullanılan ilaçlar; kortikosteroid ve bronkodilatörlerdir. Astım duyarlı bireylerde farklı derecelerde ve yaygın havayolu obstrüksiyonu ile seyreden bir enflamasyondur (35). Astım çoğunlukla tedavi yapılmadan kendiliğinden düzelebilir ya da tedaviye iyi yanıt verir. Astımın tedavisinde sistemik kortikosteroidler, bronkodilatörler, lökotrien modifiye edici ajanlar ve antienflamatuar ajanlar kullanılmaktadır $(3,6,7)$. Astım hastalığının ve astım ilaçlarının ağız ve diş sağlığı üzerine pek çok etkisinin olduğu düşünülmektedir.

Bu çalışmanın amacı, inhaler ilaç kullanan astımlı çocuklarda bu ilaçların, oral sağlık durumları üzerine etkilerinin ortaya konulmasını sağlamak ve bu ortaya konan yan etkilere karşı önlem alınabilinmesi adına gerekli farkındalığın oluşturulmasına katkıda bulunmaktır.

\section{Gereç ve Yöntem}

Bu çalışması gerekli izinler alınarak D. Ü. Diş Hek. Fak. Çocuk Diş Hek. AbD. Polikliniği ve S. B. Diyarbakır Çocuk Hastalıkları Hastanesi Çocuk İmmünolojisi ve Alerjisi Bölümü polikliniğinde yapılmıştır. Çalışmaya dâhil edilecek hastaların son aylar içerisinde dental tedavi, diş eti tedavisi, ağız içi dokularda veya tükürükte değ işikliğe neden olabilecek bir tedavi görmemiş olmalarına dikkat edilmiştir.

Herhangi bir sağlık problemi olmayan, 12 (5 kız, 7 erkek) çocuk hasta, çalışmaya kontrol grubu olarak alınmıştır. S. B. Diyarbakır Çocuk Hastalıkları Hastanesi Çocuk İmmünolojisi ve Alerjisi Bölümü’nde klinik teşhis olarak astım tanısı kesinleşmiş olan ve 1 ya da 2 yıldır inhaler ilaç kullanan fakat bu ilaç dışında başka bir ilaç kullanmayan ve kooperasyon gösteren 36 çocuk hasta ( 13 kız, 23 erkek) çalışma grubu olarak çalışmaya alınmıştır. Hasta seçiminde kooperasyon güçlüğü olmaması amacıyla $4-16$ yaş aralığındaki çocuklar çalışmaya dâhil edilmiştir.

Standardizasyonu sağlamak için çalışma grubundaki hastalar 3'e ayrılmıştır.

I.alt grup; ölçülü doz tipte inhaler ilacı direkt kullanan 12 hasta,

II. alt grup; ölçülü doz tipte inhaler ilacı bir ara cihaz aracıllğıyla kullanan 12 hasta,

III. alt grup; kuru toz tipte inhaler ilaç kullanan 12 hasta, olarak belirlenmiştir.

Toplam 48 çocuk hasta ile yapılan bu çalışmada amacımız; çalışma grupları ve kontrol grubu arasında tükürük akış hızı, tükürük pH' s1, tükürük tamponlama kapasitesi, tükürük viskozitesi, plak varlığı farklılıklarının araştırılmasıdır.

Tükürük örneği alınacak tüm hastalardan kahvaltılarını yapmış (üzerinden 2 saat geçmiş), çalışma grubundaki hastalar inhaler ilaçlarını kullanmış, ağızlarını çalkalamış ve dişlerini firçalamış olarak sabah 9-10 saatleri arasında gelmeleri istenmiştir.

Uyarılmamış tükürük akış hızı ölçümü; hastanın alt dudağı bir spanç yardımıyla silinip labial minör tükürük bezlerinden tükürük oluşumu beklenmiştir. Bir süreölçer yardımı ile bu süre saniye olarak not edilmiştir. Yorumlama şu şekilde yapılmıştır; $60 \mathrm{sn}<\mathrm{az}, 60 \mathrm{sn}>$ normal.

Uyarılmış tükürük akış hızı ölçümü; parafin tablet hastaların tükürük salgılarını uyarmak için kullanılmıştır. Hastalardan 30 sn boyunca parafin tableti çiğneyip ilk tükürüklerini yuttuktan sonra her 30 sn'de bir 5 dakika boyunca tükürükleri milimetrik dereceli tükürük toplama kaplarına alınmıştır. Kap üzerindeki ml işaretlerine göre tükürük miktarı ölçülmüş ve tükürük akış hızı ml/dk olarak hesaplanmıştır. Ölçüm sonuçları şu şekilde değerlendirilmiştir. 5 dakikadaki tükürük miktarı: $<3,5 \mathrm{ml}$ Çok Düşük, 3,5 ila 5,0 $\mathrm{ml}$ arası Düşük, $>5,0 \mathrm{ml} \mathrm{Normal}$. Tükürük pH ölçümü; hastanın tükürüğü toplama kabına alınmış ve daha sonra GC Saliva Check-Buffer kiti içerisindeki pH stribi tükürük toplama kabı içine konulup, 10 sn bekletilmiştir. Stribin aldığı renge göre pH ölçümü yapılmıştır (düşük pH: 5,0 ile 5,8 arası, ortalama pH: 6,0 ile 6,6 arası, sağlıklı pH: 6,8 ile 7,8 arası).

Tükürük tamponlama kapasitesinin ölçümü; tükürük toplama kabından bir miktar tükürük pipet yardımı ile alını tükürük tamponlama test stribi üzerinde bulunan 3'lü pede birer damla damlatılmıştır. Her 3 pedin aldığı renklere göre puan verilerek sonuç hesaplanmıştır (yeşil 4, yeşillmavi 3, mavi 2, kırmızılmavi 1, kırmızı 0 olarak hesaplanıp çıkan sonuca göre değerlendirilmiştir). Her rengin matematiksel karşıllığ olan sayılar toplanmış ve ölçüm bu şekilde yapılmıştır. Bu ölçüm sonucuna göre:3 ile 5 arası çok düşük, 6 ile 9 arası düşük, 10 ile 12 arası normallyüksek.

Tükürük viskozite ölçümü; dinlenir durumdaki tükürüğün viskozite ölçümü görsel olarak yapılmıştır. Yüksek viskozite (yapışkan, köpüklü tükürük), artmış viskozite (köpüklü, balonlu tükürük), normal viskozite (sulu, temiz tükürük) olarak not edilmiştir. 
Hastaların plak indeksi değerleri de Silness ve Löe plak indeksine göre, dişler, hava spreyinden sıkılan hava ile kurutularak yapılmıştır.

Tüm bu parametrelere hastanın dental işlemlerinin bitirilip, ağız ve diş bakımı hakkında doğru bilgilendirilmesi ve yönlendirilmesi yapıldıktan sonra her hastada standardı yakalamak amacıyla ilk muayeneden bir ay sonra (2. ölçüm) tekrar bakılmıştır.

İstatistiksel verilerin ölçümü; tanımlayıcı istatistik olarak ortalama, standart sapma, standart hata, minimum ve maksimum, sıra ortalama değerleri verilmiş olup, sürekli değişkenlerin normallik dağılım varsayımına uygunluğu Kolmogorov-Smirnow testiyle, homojenliği ise Levene testi ile araştırılmıştır.

Bağımsız gruplara ait ortalamalar arası farkların karşılaştırılmasında parametrik analiz testlerinden ANOVA(One Way ANOVA), Tukey HSD, non-parametrik analiz testlerinden Kruskall-Wallis, Mann-Whitney U testleri, bağımlı gruplara ait ortalamalar arası farkların karşılaştırılmasında parametrik analiz testlerinden Paired t-testleri kullanılmıştır.

Kategorik değişkenlerin (frekans, yüzde hesabi) istatistiksel değerlendirilmesinde Pearson Ki-Kare ve Mc-Nemar Ki-Kare testlerinden yararlanılmıştır.

İstatistik analiz testlerinde \% 95'lik güven aralığı uygulanmış olup; tanımlayıcı istatistikler ve analizler R sürüm 3.2.3 (2015-12-10), Copyright (C) 2015 The R Foundation for Statistical Computing free software bilgisayar paket programı kullanılarak yapılmıştır. " $\mathrm{p}<0,05$ " için sonuçlar istatistiksel olarak anlamlı kabul edilmiştir.

\section{Bulgular}

Uyarılmamış tükürük akış hızı ölçümü sonucu; her üç çeşit inhaler ilaç kullanma yönteminde de kontrol grubundaki çocuk hastalara göre istatistiksel olarak anlamlı bir farklılık görülmemiştir (Tablo 1).

Tablo 1. Gruplar arası ilk geliş uyarılmamış tükürük parametrelerinin istatistik ve analiz sonuçları

\begin{tabular}{lcc}
\hline Gruplar & $\mathrm{n}$ & Sira ortalaması \\
\hline Ölçülü Doz İnhaler & 12 & 20 \\
Ölçülü Doz + & 12 & 24 \\
Ara Cihaz & & \\
Kuru Toz İnhaler & 12 & 24 \\
Kontrol & 12 & 30 \\
\hline
\end{tabular}

$\mathrm{p}=0,2376$

Hastaların dental işlemlerinin bitirilip, ağız ve diş bakımı hakkında doğru bilgilendirilmesi ve yönlendirilmesi sonucunda yapılan değerlendirmelerinde (2.geliş) ise uyarılmamış tükürük akış hızı her 4 grupta da anlamlı bir değişiklik göstermemiştir (Tablo 2). Tablo 3'te görülen uyarılmış tükürük akış hızında sadece ÖDİ ilacı direkt kullanan ile kontrol grubundaki çocuk hastalar arasında anlamlı bir farklılık bulunmuştur $(\mathrm{p}<0,05)$.

Tablo 4'de de görüldüğü gibi KTİ ilaç kullanan grupta uyarılmış tükürük akış hızının 2.gelişte ilk gelişlerine göre değişimi istatistiksel olarak anlamlı bulunmuştur $(\mathrm{p}=0,0047)$. Diğer üç grupta istatistiksel olarak anlamlı bir değişim olmamıştır.

ÖDİ ilacı direkt kullananların tükürük pH'sının ÖDİ ilacı bir ara cihaz yardımıyla kullanan, KTİ ilaç kullanan ve kontrol grubundaki çocuk hastalar daha düşük olduğu tespit edilmiştir $(\mathrm{p}<0,05)$ (Tablo 5).

Tablo 6'da tükürük pH'sının ilk ve ikinci gelişteki farklarının değerlendirmesinde değişiklik ÖDİ ilacı direkt kullanan ve ÖDİ ilacı bir ara cihaz aracılığ 1 ile kullananlarda istatistiksel olarak anlamlı bulunmuştur. Diğer iki grupta istatistiksel olarak anlamlı bir değişim olmamıştır.

Tükürük tamponlama kapasitesi ÖDİ ilacı direkt ya da bir ara cihaz yardımı ile kullanan ve KTİ kullananlar arasında belirgin bir farklılık göstermezken kontrol grubundaki hastaların tükürük tamponlama kapasitesi ÖDİ ilacı bir ara cihaz yardımı ile kullanan ve KTİ ilaç kullanan çocuk hastalardan yüksektir $(\mathrm{p}<0,05)$ (Tablo 7).

Tablo 8'de hastaların ilk ve ikinci gelişlerindeki tükürük tamponlama kapasitesi arasında ÖDİ ilacı direkt ya da bir ara cihaz aracılığıyla kullanan çocuk hastalarda istatistiksel olarak anlamlı bir değişim bulunmuştur. Diğer iki grupta istatistiksel olarak anlamlı bir değişim olmamıştır. 
Tablo 2. Farklı gruplara göre uyarılmamış tükürük parametrelerinin istatistik ve analiz sonuçları

\begin{tabular}{|c|c|c|c|c|c|}
\hline \multirow{2}{*}{ Gruplar } & \multirow{2}{*}{$\begin{array}{l}\text { UYARILMAMIŞ } \\
\text { TÜKÜRÜK-2 }\end{array}$} & \multicolumn{2}{|c|}{$\begin{array}{l}\text { UYARILMAMIŞ } \\
\text { TÜKÜRÜK-1 }\end{array}$} & \multirow{2}{*}{ Toplam } & \multirow{2}{*}{$\begin{array}{c}\text { McNemar } \\
\text { test }\end{array}$} \\
\hline & & $\begin{array}{l}60 \text { Sn'den } \\
\text { Kisa }\end{array}$ & $\begin{array}{l}60 \text { Sn'den } \\
\text { Uzun }\end{array}$ & & \\
\hline \multirow{3}{*}{$\begin{array}{l}\text { Ölçülü } \\
\text { Doz } \\
\text { İnhaler }\end{array}$} & 60 Sn'den Kısa & 2 & 5 & $7(58,3 \%)$ & \multirow{3}{*}{$\mathrm{p}=0,2188$} \\
\hline & 60 Sn'den Uzun & 1 & 4 & $5(41,7 \%)$ & \\
\hline & Toplam & $3(25,0 \%)$ & $9(75,0 \%)$ & 12 & \\
\hline \multirow{2}{*}{$\begin{array}{l}\text { Ölçülü } \\
\text { Doz }\end{array}$} & 60 Sn'den Kisa & 4 & 4 & $8(66,7 \%)$ & \multirow{4}{*}{$\mathrm{p}=0,3750$} \\
\hline & 60 Sn'den Uzun & 1 & 3 & $4(33,3 \%)$ & \\
\hline+ & & & & & \\
\hline $\begin{array}{l}\text { Ara } \\
\text { Cihaz }\end{array}$ & Toplam & $5(41,7 \%)$ & $7(58,3 \%)$ & 12 & \\
\hline \multirow{3}{*}{$\begin{array}{l}\text { Kuru Toz } \\
\text { İnhaler }\end{array}$} & 60 Sn'den Kisa & 3 & 0 & $3(25,0 \%)$ & \multirow{3}{*}{$\mathrm{p}=0,5000$} \\
\hline & 60 Sn'den Uzun & 2 & 7 & $9(75,0 \%)$ & \\
\hline & Toplam & $5(41,7 \%)$ & $7(58,3 \%)$ & 12 & \\
\hline \multirow{3}{*}{ Kontrol } & 60 Sn'den Kisa & 8 & 3 & $11(91,7)$ & \multirow{3}{*}{$\mathrm{p}=0,2500$} \\
\hline & 60 Sn'den Uzun & 0 & 1 & $1(8,3 \%)$ & \\
\hline & Toplam & $8(66,7 \%)$ & $4(33,3 \%)$ & 12 & \\
\hline
\end{tabular}

Tablo 3. Gruplar arası ilk geliş uyarılmış tükürük parametrelerinin istatistik ve analiz sonuçları

\begin{tabular}{lccc}
\hline Gruplar & $\mathrm{n}$ & Average Rank & Fark $(\mathrm{p}<0,05)$ \\
\hline Ölçülü Doz İnhaler & 12 & 17 & Kontrol \\
Ölçülü Doz + & 12 & 24,54 & \\
Ara Cihaz & 12 & 23 & \\
Kuru Toz İnhaler & 12 & 33,46 & Ölçülü Doz İnhaler \\
Kontrol & & & \\
\hline
\end{tabular}

$$
\mathrm{p}=0,0198
$$


International Journal of Scientific and Technological Research

ISSN 2422-8702 (Online), DOI: 10.7176/JSTR/5-3-10

Vol.5, No.3, 2019

Tablo 4. Farklı gruplara göre uyarılmış tükürük parametrelerinin istatistik ve analiz sonuçları

\begin{tabular}{|c|c|c|c|c|c|c|c|}
\hline \multirow[b]{2}{*}{ Gruplar } & \multirow[b]{2}{*}{$\begin{array}{l}\text { UYARILMIŞ } \\
\text { TÜKÜRÜK-2 }\end{array}$} & \multicolumn{3}{|c|}{ UYARILMIŞ TÜKÜRÜK-1 } & \multirow[b]{2}{*}{ Toplam } & \multirow{2}{*}{$\begin{array}{c}\text { Chi- } \\
\text { Square } \\
\text { test }\end{array}$} & \multirow[b]{2}{*}{$\mathrm{p}$} \\
\hline & & $\begin{array}{l}3.5 \text { ile } 5 \\
\mathrm{ml} \text { arası }\end{array}$ & $\begin{array}{c}3.5 \text { ml'den } \\
\text { az }\end{array}$ & $\begin{array}{l}5 \text { ml'den } \\
\text { fazla }\end{array}$ & & & \\
\hline \multirow{4}{*}{$\begin{array}{l}\text { Ölçülü } \\
\text { Doz } \\
\text { İnhaler }\end{array}$} & $\begin{array}{c}3.5 \text { ile } 5 \mathrm{ml} \\
\text { arası }\end{array}$ & 5 & 1 & & $6(50,0 \%)$ & \multirow{4}{*}{2,850} & \multirow{4}{*}{0,2405} \\
\hline & 3.5 ml'den az & 0 & 1 & & $1(8,3 \%)$ & & \\
\hline & 5 ml'den fazla & 3 & 2 & & $5(41,7 \%)$ & & \\
\hline & Toplam & $8(66,7 \%)$ & $4(33,3 \%)$ & & 12 & & \\
\hline $\begin{array}{l}\text { Ölçülü } \\
\text { Doz }\end{array}$ & $\begin{array}{c}3.5 \text { ile } 5 \mathrm{ml} \\
\text { aras } 1\end{array}$ & 4 & 1 & 2 & $7(58,3 \%)$ & \multirow{4}{*}{2,405} & \multirow{4}{*}{0,6618} \\
\hline+ & 3.5 ml'den az & 1 & 1 & 1 & $3(25,0 \%)$ & & \\
\hline \multirow{2}{*}{$\begin{array}{l}\text { Ara } \\
\text { Cihaz }\end{array}$} & 5 ml'den fazla & 0 & 1 & 1 & $2(16,7 \%)$ & & \\
\hline & Toplam & $5(41,7 \%)$ & $3(25,0 \%)$ & $4(33,3 \%)$ & 12 & & \\
\hline \multirow{4}{*}{$\begin{array}{l}\text { Kuru Toz } \\
\text { İnhaler }\end{array}$} & $\begin{array}{c}3.5 \text { ile } 5 \mathrm{ml} \\
\text { arası }\end{array}$ & 5 & 1 & 0 & $6(50,0 \%)$ & \multirow{4}{*}{15,000} & \multirow{4}{*}{0,0047} \\
\hline & $3.5 \mathrm{ml}$ 'den az & 1 & 2 & 0 & $3(25,0 \%)$ & & \\
\hline & 5 ml'den fazla & 0 & 0 & 3 & $3(25,0 \%)$ & & \\
\hline & Toplam & $6(50,0 \%)$ & $3(25,0 \%)$ & $3(25,0 \%)$ & 12 & & \\
\hline \multirow{4}{*}{ Kontrol } & $\begin{array}{c}3.5 \text { ile } 5 \mathrm{ml} \\
\text { aras } 1\end{array}$ & 1 & 0 & 1 & $2(16,7 \%)$ & \multirow{4}{*}{0,900} & \multirow{4}{*}{0,6376} \\
\hline & $3.5 \mathrm{ml}$ 'den az & & & & & & \\
\hline & 5 ml'den fazla & 2 & 1 & 7 & $10(83,3 \%)$ & & \\
\hline & Toplam & $3(25,0 \%)$ & $1(8,3 \%)$ & $8(66,7 \%)$ & 12 & & \\
\hline
\end{tabular}

Tablo 5. Gruplar arası ilk geliş tükürük pH'sı parametrelerinin istatistik ve analiz sonuçları

\begin{tabular}{lccc}
\hline Gruplar & $\mathrm{n}$ & Ortalama & Fark (p<0,05) \\
\hline Ölçülü Doz İnhaler & 12 & 6,5667 & $\begin{array}{c}\text { Ölçülü Doz + Ara Cihaz, } \\
\text { Kuru Toz İnhaler, } \\
\text { Kontrol }\end{array}$ \\
$\begin{array}{l}\text { Ölçülü Doz } \\
+\end{array}$ & 12 & 7,0333 & Ölçülü Doz İnhaler \\
Ara Cihaz & 12 & 7,2000 & Ölçülü Doz İnhaler \\
Kuru Toz İnhaler & 12 & 7,5000 & Ölçülü Doz İnhaler \\
Kontrol & & &
\end{tabular}


Tablo 6. Farklı gruplara göre tükürük pH'sı parametrelerinin istatistik ve analiz sonuçları

\begin{tabular}{lcccccc}
\hline Gruplar & Dönemler & $\mathrm{n}$ & $\begin{array}{c}\text { Ortala } \\
\text { ma }\end{array}$ & $\begin{array}{c}\text { Std. } \\
\text { sapma }\end{array}$ & $\begin{array}{c}\text { Ortalama } \\
\text { std. hata }\end{array}$ & P \\
\hline Ölçülü Doz İnhaler & $\begin{array}{l}\text { Tükürük pH-1 } \\
\text { Tükürük pH-2 }\end{array}$ & 12 & 6,567 & 0,5033 & 0,1453 & 0,004 \\
& Tükürük pH-1 & 12 & 7,033 & 0,5710 & 0,1648 & \\
Ölçülü Doz & Tükürük pH-2 & 12 & 7,300 & 0,5081 & 0,1467 & 0,031 \\
Ara Cihaz & Tükürük pH-1 & 12 & 7,200 & 0,4264 & 0,1231 & 0,318 \\
\hline \multirow{2}{*}{ Kuru Toz inhaler } & Tükürük pH-2 & 12 & 7,283 & 0,3762 & 0,1086 & \\
\hline \multirow{2}{*}{ Kontrol } & Tükürük pH-1 & 12 & 7,500 & 0,4390 & 0,1267 & 0,214 \\
& Tükürük pH-2 & 12 & 7,583 & 0,2887 & 0,0833 & \\
\hline
\end{tabular}

Tablo 7. Gruplar arası ilk geliş tükürük tamponlama kapasitesi parametrelerinin istatistik ve analiz sonuçları

\begin{tabular}{|c|c|c|c|}
\hline Gruplar & $\mathrm{n}$ & Ortalama & Fark $(\mathrm{p}<0,05)$ \\
\hline Ölçülü Doz İnhaler & 12 & 7,1667 & \\
\hline $\begin{array}{l}\text { Ölçülü Doz + } \\
\text { Ara Cihaz }\end{array}$ & 12 & 6,7500 & Kontrol \\
\hline Kuru Toz İnhaler & 12 & 6,5000 & Kontrol \\
\hline Kontrol & 12 & 8,5833 & $\begin{array}{c}\text { Ölçülü Doz + Ara } \\
\text { Cihaz, Kuru Toz } \\
\text { İnhaler }\end{array}$ \\
\hline
\end{tabular}


Tablo 8. Farklı gruplara göre tükürük tamponlama kapasitesi parametrelerinin istatistik ve analiz sonuçları

\begin{tabular}{|c|c|c|c|c|c|c|}
\hline Gruplar & Dönemler & $\mathrm{n}$ & Ortalama & $\begin{array}{l}\text { Std. } \\
\text { sapma }\end{array}$ & $\begin{array}{l}\text { Ortalama } \\
\text { std. hata }\end{array}$ & $\mathrm{p}$ \\
\hline \multirow{2}{*}{$\begin{array}{l}\text { Ölçülü Doz } \\
\text { İnhaler }\end{array}$} & $\begin{array}{l}\text { Tükürük Tamponlama } \\
\text { Kapasitesi-1 }\end{array}$ & 12 & 7,17 & 1,337 & 0,386 & \multirow[b]{2}{*}{0,000} \\
\hline & $\begin{array}{l}\text { Tükürük Tamponlama } \\
\text { Kapasitesi-2 }\end{array}$ & 12 & 8,42 & 1,443 & 0,417 & \\
\hline \multirow{2}{*}{$\begin{array}{l}\begin{array}{l}\text { Ölçülü Doz } \\
+\end{array} \\
\text { Ara Cihaz }\end{array}$} & $\begin{array}{l}\text { Tükürük Tamponlama } \\
\text { Kapasitesi-1 }\end{array}$ & 12 & 6,75 & 2,137 & 0,617 & \multirow{2}{*}{0,004} \\
\hline & $\begin{array}{l}\text { Tükürük Tamponlama } \\
\text { Kapasitesi-2 }\end{array}$ & 12 & 7,92 & 1,379 & 0,398 & \\
\hline \multirow{2}{*}{$\begin{array}{l}\text { Kuru Toz } \\
\text { inhaler }\end{array}$} & $\begin{array}{l}\text { Tükürük Tamponlama } \\
\text { Kapasitesi-1 }\end{array}$ & 12 & 6,50 & 1,732 & 0,500 & \multirow{2}{*}{0,408} \\
\hline & $\begin{array}{l}\text { Tükürük Tamponlama } \\
\text { Kapasitesi-2 }\end{array}$ & 12 & 6,92 & 1,975 & 0,570 & \\
\hline \multirow{2}{*}{ Kontrol } & $\begin{array}{l}\text { Tükürük Tamponlama } \\
\text { Kapasitesi-1 }\end{array}$ & 12 & 8,58 & 1,782 & 0,514 & \multirow{2}{*}{0,504} \\
\hline & $\begin{array}{l}\text { Tükürük Tamponlama } \\
\text { Kapasitesi-2 }\end{array}$ & 12 & 8,92 & 1,730 & 0,499 & \\
\hline
\end{tabular}

Tükürük viskozitesinde sağlıklı ve inhaler ilaç kullanan bireyler arasında anlamlı bir değişiklik tespit edilmemiştir (Tablo 9). İlk ve ikinci geliş arasındaki değişikliğe bakılınca ÖDİ ilacı direkt kullanan ve kontrol grubundaki çocuk hastalarda tükürük viskozitesi düşmüştür. Diğer iki grupta istatistiksel olarak anlamlı bir değişim olmamıştır (Tablo 10).

ÖDİ ilacı direkt kullanan çocuk hastaların, ÖDİ ilacı bir ara cihaz aracılığıyla kullanan çocuk hastaların, KTİ ilaç kullanan çocuk hastaların kendi aralarında plak birikimi büyük bir farklılık göstermezken inhaler ilaç kullanan tüm bireylerde kontrol grubundaki çocuk hastalardan fazla miktarda plak birikimi vardır (Tablo 11). Her bir grup için ayrı plak indeksi ölçümlerinin ilk geliş ikinci geliş arasındaki değerlendirilme sonucu değişim istatistiksel olarak anlamlı bulunmamıştır (Tablo 12).

Tablo 9. Gruplar arası ilk geliş tükürük viskozitesi parametrelerinin istatistik ve analiz sonuçları

\begin{tabular}{lcc}
\hline Gruplar & $\mathrm{n}$ & Sira ortalaması \\
\hline Ölçülü Doz İnhaler & 12 & 20,83 \\
Ölçülü Doz & 12 & \\
+ & & 22,67 \\
Ara Cihaz & 12 & \\
Kuru Toz İnhaler & 12 & 25,42 \\
Kontrol & & 29,08 \\
\hline
\end{tabular}


International Journal of Scientific and Technological Research

ISSN 2422-8702 (Online), DOI: 10.7176/JSTR/5-3-10

Vol.5, No.3, 2019

Tablo 10. Farklı gruplara göre tükürük vizkositesi parametrelerinin istatistik ve analiz sonuçları

\begin{tabular}{|c|c|c|c|c|c|c|c|}
\hline \multirow[b]{2}{*}{ Gruplar } & \multirow[b]{2}{*}{$\begin{array}{c}\text { TÜKÜRÜK } \\
\text { VİSKOZİTESİ-2 }\end{array}$} & \multicolumn{3}{|c|}{ TÜKÜRÜK VİZKOSİTESİ-1 } & \multirow[b]{2}{*}{ Toplam } & \multirow{2}{*}{$\begin{array}{l}\text { Chi- } \\
\text { Square } \\
\text { test }\end{array}$} & \multirow[b]{2}{*}{$\mathrm{p}$} \\
\hline & & Berrak & $\begin{array}{c}\text { Köpüklü } \\
\text { Baloncuklu }\end{array}$ & $\begin{array}{l}\text { Yoğun } \\
\text { Vizköz }\end{array}$ & & & \\
\hline \multirow{4}{*}{$\begin{array}{l}\text { Ölçülü } \\
\text { Doz } \\
\text { İnhaler }\end{array}$} & Berrak & 4 & 0 & & $4(33,3 \%)$ & \multirow{4}{*}{8,400} & \multirow{4}{*}{0,004} \\
\hline & $\begin{array}{c}\text { Köpüklü } \\
\text { Baloncuklu }\end{array}$ & 1 & 7 & & $8(66,7 \%)$ & & \\
\hline & Yoğun Vizköz & 0 & 0 & & & & \\
\hline & Toplam & $5(41,7 \%)$ & $7(58,3 \%)$ & & 12 & & \\
\hline \multirow{4}{*}{$\begin{array}{l}\text { Ölçülü } \\
\text { Doz } \\
+ \\
\text { Ara } \\
\text { Cihaz }\end{array}$} & Berrak & 1 & 2 & & $3(25,3 \%)$ & \multirow{4}{*}{0,000} & \multirow{4}{*}{0,1000} \\
\hline & $\begin{array}{c}\text { Köpüklü } \\
\text { Baloncuklu }\end{array}$ & 3 & 6 & & $9(75,0 \%)$ & & \\
\hline & Yoğun Vizköz & & & & & & \\
\hline & Toplam & $4(33,3 \%)$ & $8(66,7 \%)$ & & 12 & & \\
\hline \multirow{4}{*}{$\begin{array}{l}\text { Kuru Toz } \\
\text { İnhaler }\end{array}$} & Berrak & 1 & & & $6(50,0 \%)$ & \multirow{4}{*}{2,182} & \multirow{4}{*}{0,336} \\
\hline & $\begin{array}{c}\text { Köpüklü } \\
\text { Baloncuklu }\end{array}$ & 3 & 6 & 2 & $3(25,0 \%)$ & & \\
\hline & Yoğun Vizköz & & & & $3(25,0 \%)$ & & \\
\hline & Toplam & $4(33,3 \%)$ & $6(50,0 \%)$ & $2(16,7 \%)$ & 12 & & \\
\hline \multirow{4}{*}{ Kontrol } & Berrak & 2 & 1 & & $3(25,3 \%)$ & \multirow{4}{*}{7,333} & \multirow{4}{*}{0,026} \\
\hline & $\begin{array}{c}\text { Köpüklü } \\
\text { Baloncuklu }\end{array}$ & & 7 & 2 & $9(75,3 \%)$ & & \\
\hline & Yoğun Vizköz & & & & & & \\
\hline & Toplam & $2(16,7 \%)$ & $8(66,7 \%)$ & $2(16,7 \%)$ & 12 & & \\
\hline
\end{tabular}

Tablo 11. Gruplar arası ilk geliş plak birikimi miktarı parametrelerinin istatistik ve analiz sonuçları

\begin{tabular}{lccc}
\hline Gruplar & $\mathrm{n}$ & Sira ortalaması & Fark $(\mathrm{p}<0.05)$ \\
\hline $\begin{array}{l}\text { Ölçülü Doz } \\
\text { İnhaler }\end{array}$ & 12 & 27,00 & Kontrol \\
$\begin{array}{l}\text { Ölçülü Doz } \\
+\end{array}$ & 12 & 23,00 & Kontrol \\
$\begin{array}{l}\text { Ara Cihaz } \\
\text { Kuru Toz } \\
\text { İnhaler }\end{array}$ & 12 & 29,00 & Kontrol \\
Kontrol & 12 & 19,00 & $\begin{array}{c}\text { Ölçülü Doz İnhaler, Ölçülü Doz }+ \text { Ara } \\
\text { Cihaz, Kuru Toz İnhaler }\end{array}$ \\
\hline \multicolumn{1}{c}{ p=0,0048 } & &
\end{tabular}


Tablo 12. Farklı gruplara göre plak indeks parametresinin istatistik ve analiz sonuçları

\begin{tabular}{|c|c|c|c|c|c|c|c|c|}
\hline \multirow{2}{*}{ Gruplar } & \multirow{2}{*}{$\begin{array}{l}\text { Plak } \\
\text { İndeks-2 }\end{array}$} & \multicolumn{4}{|c|}{ Plak İndeks-1 } & \multirow{2}{*}{ Toplam } & \multirow{2}{*}{$\begin{array}{l}\text { Chi- } \\
\text { Square } \\
\text { test }\end{array}$} & \multirow{2}{*}{$\mathrm{P}$} \\
\hline & & Plak Yok & İnce Plak & Orta Plak & Yoğun & & & \\
\hline \multirow{3}{*}{$\begin{array}{l}\text { Ölçülü } \\
\text { Doz } \\
\text { İnhaler }\end{array}$} & Plak Yok & & 5 & 4 & & $9(75,0 \%)$ & \multirow{3}{*}{0,114} & \multirow{3}{*}{0,7353} \\
\hline & İnce Plak & & 2 & 1 & & $3(25,0 \%)$ & & \\
\hline & Toplam & & $7(58,3 \%)$ & $5(41,7 \%)$ & & 12 & & \\
\hline \multirow{2}{*}{$\begin{array}{l}\text { Ölçülü } \\
\text { Doz }\end{array}$} & Plak Yok & 1 & 3 & & & $4(33,3 \%)$ & \multirow{3}{*}{0,750} & \multirow{3}{*}{0,6873} \\
\hline & İnce Plak & 1 & 6 & & 1 & $8(66,7 \%)$ & & \\
\hline \multirow[t]{2}{*}{$\begin{array}{l}\text { Ara } \\
\text { Cihaz }\end{array}$} & Toplam & $2(16,7 \%)$ & $9(45,0 \%)$ & & $1(8,3 \%)$ & 12 & & \\
\hline & Plak Yok & & 3 & 3 & & $6(50,0 \%)$ & \multirow{3}{*}{0,333} & \multirow{3}{*}{0,5637} \\
\hline \multirow{2}{*}{$\begin{array}{l}\text { Kuru Toz } \\
\text { İnhaler }\end{array}$} & İnce Plak & & 3 & 3 & & $6(50,0 \%)$ & & \\
\hline & Toplam & & $6(50,0 \%)$ & $6(50,0 \%)$ & & 12 & & \\
\hline \multirow{3}{*}{ Kontrol } & Plak Yok & 4 & 4 & 1 & & $9(75,0 \%)$ & \multirow{3}{*}{0,622} & \multirow{3}{*}{0,7326} \\
\hline & İnce Plak & 1 & 2 & & & $3(25,0 \%)$ & & \\
\hline & Toplam & $5(41,7 \%)$ & $6(50,0 \%)$ & $1(8,3 \%)$ & & 12 & & \\
\hline
\end{tabular}

\section{Tartışma}

Çocuk diş hekimleri için çocuklarda sık rastlanılan sistemik hastalıklar ve bu sistemik hastalıklara ya da bu hastalıklarda kullanılan ilaçlara bağlı olarak görülen ağız bulguları büyük önem teşkil etmektedir. Sistemik, virütik, genetik ve bakteriyel pek çok hastalık ilk belirtilerini ağız içerisinde vermektedir. Bunun yanı sıra bazı hastalıklarda kullanılan ilaçlar da ağız içi mukozasını, dişleri ya da tükürüğü etkileyebilmektedir. Tükürük durumunu ve çürük miktarını etkileyebileceği düşünülen bir ilaç grubu da inhaler ilaçlardır $(3,4,6)$. Bizde çalışmamızda, inhaler ilaç kullanan astımlı çocukların, inhaler ilaçların ağız ve diş sağlığı üzerine etkilerinin ortaya çıkarılmasını amaçladık. Bu amaçla hastaların; tükürük akış hızı, tükürük pH’sı, tükürük tamponlama kapasitesi, tükürük viskozitesi, plak varlığı farklılıkları değerlendirilmiştir.

Biz çalışmamızda yaş grubu alt sınırını 4, üst sınırını ise 16 olarak belirledik. Vandewalker ve ark. (8) 'astımlı pediatrik hastalarda beklometason dipropionat nefes aktivasyonlu veya ölçülü doz inhalerinin etkinliği ve güvenilirliği’ isimli araştırmasında alt sınırı bizim çalışmamızda da olduğu gibi 4, üst sınırı ise 11 olarak belirlemiştir. McDerra ve ark. alt ve üst yaş sınırını bizim çalışmamızla aynı olarak sırasıyla 4 ve 16 olarak belirlemiştir. Eloot ve ark. 2004 yılında yaptıkları bir çalışmada yaş aralığını 3-17, Shashikiran ve ark. 6-14 olarak belirlemiştir (9).

Shashikirian ve ark. (10) ilaç kullanımının etkisini tespit edebilmek için astım hastası 105 çocuğun salbutamol inhaler, salbutamol tablet ve beklametazon inhaler kullanımını ilaca başladıkları ilk yıl takip etmişlerdir. Bizim çalışmamızla paralel olarak birinci yılsonunda ki değişikliklere bakmışlardır fakat farklı olarak ilaç başlangıcı ve birinci yıl sonucu araştırılmıştır.

İnhaler ilaç kullanma tipleri temelde 3'e ayrilır;

1. Nebülizer

2. Ölçülü doz inhaler (ÖDİ)

a.Direkt kullanım

b. Ara cihaz ile kullanım

3. Kuru toz inhaler (KTI)

Çalışmamıza nebülizer tipi dâhil etmememizin nedeni ise daha çok iki yaşından küçük çocuklarda tercih edilmesi $(1,2)$ ve 2 yaş altının bizim çalışma grubumuza girmemesidir. Ayrıca pahalı olması, kontaminasyona açık olması, taşınmasının zor olması, basınçlı gaz gereksinimi, fazla zaman gerektirmesi ve hazırlık gerektirmesi de tercih edilme durumunu azaltmaktadır $(1,2)$.

Arafa ve ark. (11) 2017 astımlılarda tükürük akış hızının sağlıklılardan daha az olduğunu ileri sürmüşlerdir. Astım hastalarında sadece bronkodilatör kullanımı değil ağız solunumu varlığı da ağız kuruluğunu artırabilmektedir.

80 | P a g e

www.iiste.org 
Tükürük akışındaki azalma ayrıca tükürük içerisindeki amilaz, total protein, peroksidaz, sekretuvar IgA ve lizozim oranlarını da azaltmaktadır $(3,4,12)$. IgA, önemli birçok antibakteriyel etkinlik gösterir ve bakteriyel adezyonu engellemektedir. Diğerleri ise (tükürük peroksidaz, lizozim ve laktoferrin gibi) bakteri metabolizmasına etki eder. Tükürük antibakteriyel kapasitesi düşmesi dolayısıyla hasta ağız ve diş hastalıklarına daha yatkın hale gelebilir (13).

Bizim çalışmamızda da tükürük ile ilgili parametrelerin (uyarılmamış ve uyarılmış tükürük akış hızı, tükürük pH'sı, tükürük tamponlama kapasitesi, tükürük viskozitesi) ölçümü şu şekilde sonuç vermiştir. Uyarılmamıș tükürük akış hızı ölçümü sonucu; her üç çeşit inhaler ilaç kullanma yönteminde de kontrol grubundaki çocuk hastalara göre istatistiksel olarak anlamlı bir farklılık görülmemiştir ( $\mathrm{p}=0,2379)$. İkinci değerlendirmede ise her 4 grupta da uyarılmamış tükürük akış hızı istatistiksel olarak değişmemiştir (ÖDİ kullananlar için p=0,2188, ÖDİ'i bir ara cihaz aracılığıyla kullananlar için $p=0,3750$, KTİ kullananlar için $p=0,5000$, kontrol grubu için $p=0,2500$ ). Uyarılmış tükürük akış hızı ölçümü sonucu; sadece ÖDİ ilacı direkt kullananlar ile kontrol grubundaki hastalar arasında anlamlı bir farklılık bulunmuştur $(\mathrm{p}<0,05)$. Hastaların ikinci kez değerlendirilmesinde ise sadece KTÍ ilaç kullananların uyarılmış tükürük akış hızı artmıştır $(\mathrm{p}=0,0047)$. Diğer 3 grupta ise uyarılmış tükürük akış hızı değişmemiştir (ÖDİ'i direkt kullananlar için p=0,2405, ÖDİ'i bir ara cihaz aracılığıyla kullananlar için p=0,6618, kontrol grubu için $\mathrm{p}=0,6376$ ). ÖDİ'i direkt kullanan hastaların tükürük pH'sının ÖDİ'i bir ara cihaz yardımıyla kullanan, KTİ ilaç kullanan ve kontrol grubundaki hastalardan daha düşük olduğu tespit edilmiştir (p<0,05). ÖDİ'i direkt kullanan ve ara cihaz yardımıyla kullanan hastalarda 2. değerlendirmede tükürük pH'sının istatistiksel olarak anlamlı bir artışı söz konusudur (sırası ile p=0,004, p=0,031 ). Fakat KTİ kullanan ve kontrol grubundaki hastalarda tükürük pH'sındaki artış istatistiksel olarak anlamlı olmamıştır ( ilaçlarda alınan bu sonucun sebebinin tükürük pH'sını, pH: 5,5'in(hidroksilapatitin çözünmesi için kritik ) altına düşürmesi (16) olabileceği düşünülmüştür. Tükürük tamponlama kapasitesi inhaler ilaç kullanma yöntemine göre istatistiksel olarak anlamlı bir farklılık göstermezken ( $\mathrm{p}>0,05)$; kontrol grubunun tükürük tamponlama kapasitesi ÖDİ'i bir ara cihaz yardımıyla kullanan ve KTİ kullananlardan yüksektir $(p<0,05)$. Tükürük tamponlama kapasitesi 2. ölçümlerde ÖDİ'i direkt ya da bir ara cihaz aracılığıyla kullanan hastalarda artmıştır (sırasıyla $\mathrm{p}=0,000, \mathrm{p}=0,004)$. Fakat KTİ kullanan hastalarda ve kontrol grubunda artış istatistiksel olarak anlamlı olmamıştır (KTİ kullanan hastalar için $p=0,408$, kontrol grubu için $p=0,504)$. Tükürük viskozitesinde sağlıklı ve inhaler ilaç kullanan bireyler arasında anlamlı bir değişiklik tespit edilmemiştir ( $\mathrm{p}=0,3675)$. Tükürük viskozitesi 2. ölçümlerde ÖDİ'i direkt kullananlarda ve kontrol grubunda istatistiksel olarak anlamlı bir düşüş göstermiştir (ÖDİ'i direkt kullananlar için $p=0,004$, kontrol grubu için $p=0,026$ ). Tükürük viskozitesi en yüksek çıkan KTİ ilaç kullanan ve tükürük viskozitesi hemen onu takip eden ÖDİ'i bir ara cihaz aracılığıyla kullanan grupta istatistiksel olarak anlamlı bir değişim olmamıştır (ÖDİ'i bir ara cihaz aracılığıyla kullananlar için p=0,1000, KTİ ilaç kullananlar için $\mathrm{p}=0,336$ ).

Astımlı bireylerde inhaler ilaç kullanımı tükürük tamponlama kapasitesini ve tükürük akış hızını azaltmaktadır. Bu sebepten dolayı ağız kuruluğu oluşmakta ve ağız içi yıkama yeterli olamamaktadır. Dental plak artışı için ortam uygun hale gelmiş olur ve bu durum astımlı bireylerin dental plak miktarının sağlıklı bireylere oranla artmış olmasını açıklamaktadır (14,15,16). MCDerra (17) ve ark. 100 astımlı çocuk ile 1998 senesinde yaptıkları çalışmada çürük prevelansının, plak oluşumunun, diş eti iltihabının astımlı bireylerde sağlıklı bireylerden daha fazla olduğunu bildirmişlerdir. Metha ve ark. (18) 80 sağlıklı, 80 astımlı bireyle yaptıkları bir çalışmada astımlı hastalardaki plak miktarın sağlıklı hastalara göre oldukça fazla olduğunu tespit etmişlerdir. Bunların yanı sıra Stensson ve ark. (19) 2010 senesinde 20 astımlı, 20 sağlıklı, yaş ortalamaları 14 olan çocuklarla yaptıkları çalışmalarında sağlıklı ve astımlı bireylerin plak miktarı arasında fark olmadığını bulmuşlardır. Ferrazzano ve ark. (20) 2012 senesinde yaş ortalamaları 9.11 olan astımlı ve sağlıklı çocuklarla yaptıkları çalışmaları sonucunda astımlı çocukların plak miktarının sağlıklılardan farklı olmadığını bulmuşlardır.

İnhaler ilaç kullanan üç grupta kendi aralarında büyük bir farklılık göstermezken kontrol grubundaki çocuk hastalardan fazla miktarda plak birikimleri vardır ( $\mathrm{p}=0,0048)$. Her bir grup için ayrı plak indeksi ölçümlerinde (ilk ve ikince gelişler arasında) farklılık görülmemiştir (ÖDİ ilacı direkt kullanan çocuk hastalar için p=0,7353, ÖDİ ilacı bir ara cihaz aracılığıyla kullanan çocuk hastalar için $p=0,6873$, KTİ ilaç kullanan çocuk hastalar için $\mathrm{p}=0,5637$, kontrol grubundaki çocuk hastalar için $\mathrm{p}=0,7326$ ).

Tüm bu sonuçlar inhaler ilaç kullanımının diş çürüğü üzerine direkt etkisi olmasa da uyarılmamış tükürük akış hızı, tükürük pH'sı, tükürük tamponlama kapasitesi, plak miktarı ve dental erozyon gibi pek çok parametreyi etkilediğini göstermektedir.

\section{Sonuç}

İnhaler ilaç kullanan çocuklarda uyarılmış tükürük akış hızı, tükürük pH'sı, tükürük tamponlama kapasitesi ve plak miktarı gibi pek çok parametreyi inhaler ilaç kullanımın etkilediğini tespit edilmiştir. Bundan dolayı düzenli diş firçalama, rutin diş hekimi muayeneleri ve flor uygulama, fissür sealent gibi koruyucu diş hekimliği tedavileri yapilmalidir.

81 I $P$ a g e 


\section{Teşekkürler}

Dicle Üniversitesi Bilimsel Araştırmalar Projeleri Komisyonu Başkanlığı tarafindan Díş.17.018 numaralı proje ile desteklenmiştir. Teşekkür ederiz.

\section{Kaynaklar}

1. Boe J, Dennis JH, O'driscoll BR, Bauer TT, Carone M, Dautzenberg B, Lannefors L. European Respiratory Society Guidelines on the use of Nebulizers: Guidelines prepared by a European Respiratory Society Task Force on the Use of Nebulizers. European Respiratory Journal, 2001; 18(1):228-242.

2. Pekcan S. Çocuklarda İnhaler Tedavi Uygulamaları. Solunum Dergisi, 2012; 14(2):63-72.

3. Aral K, Aral CA, Ersin KR. Astım ve Ağız Sağlı̆̆ı. Ege Üniversitesi Dişhekimliği Fakültesi Dergisi, 2016; 37(2):42-46.

4. Thomas, MS, Parolia A, Kundabala M, Vikram M. Asthma and Oral Health: A Review. Australian Dental Journal, 2010; 55(2):128-133.

5. Ninan TK, Russell G. Respiratory Symptoms and Atopy in Aberdeen Schoolchildren: Evidence from Two Surveys 25 Years Apart. British Medical Journal (BMJ), 1992; 304(6831):873-875.

6. Sağ Ç, Özden FO, Açıkgöz G, Anlar FY. The Effects of Combination Treatment with a Long-Acting B $2_{2-}$ Agonist and a Corticosteroid on Salivary Flow Rate, Secretory Immunoglobulin A, and Oral Health in Children and Adolescents with Moderate Asthma: A 1-Month, Single-Blind Clinical Study. Clinical Therapeutics, 2007; 29(10):2236-2242.

7. Shulman JD, Nunn ME, Taylor SE, Rivera-Hidalgo F. The Prevalence of Periodontal-Related Changes in Adolescents with Asthma: Results of the Third Annual National Health and Nutrition Examination Survey. Pediatric Dentistry, 2003; 25(3):279-84.

8. Vandewalker M, Hickey L, Small CJ. Efficacy and Safety of Beclomethasone Dipropionate BreathActuated or Metered-Dose Inhaler in Pediatric Patients with Asthma. In: Allergy and Asthma Proceedings. OceanSide Publications, 2017;38(5):354-364.

9. Moraschini V, Calasans-Maia JDA, Calasans-Maia MD. Association between Asthma and Periodontal Disease: A Systematic Review and Meta-Analysis. Journal of Periodontology, 2018; 89(4):440-455.

10.Shashikiran ND, Reddy VVS, Raju PK. Effect of Antiasthmatic Medication on Dental Disease: Dental Caries and Periodontal Disease. Journal of Indian Society of Pedodontics and Preventive Dentistry, 2007; 25(2):65-68.

11. Arafa A, Aldahlawi S, Fathi A. Assessment of the Oral Health Status of Asthmatic Children. European Journal of Dentistry, 2017; 11(3):357-363.

12.Ryberg M, Möller G, Ericson T. Saliva Composition and Caries Development in Asthmatic Patients Treated with $\beta_{2}$-Adrenoceptor Agonists: a 4-Year Follow-Up Study. European Journal of Oral Sciences, 1991; 99(3): 212-218.

13.Ryberg M, Möller C, Ericson T. Effect of $\beta_{2}$-Adrenoceptor Agonists on Saliva Proteins and Dental Caries in Asthmatic Children. Journal of Dental Research, 1987; 66(8):1404-1406.

14.Bimstein E, Wilson J, Guelmann M, Primosch R. The Relationship between Oral and Demographic Characteristics of Children with Asthma. Journal of Clinical Pediatric Dentistry, 2007; 31(2):86-89.

15. Yaghobee S, Paknejad M, Khorsand A. Association between Asthma and Periodontal Disease. Journal of Dentistry of Tehran University of Medical Sciences, 2008; 5(2):47-51. 
16. Hyyppä TM, Koivikko A, Paunio KU. Studies on Periodontal Conditions in Asthmatic Children. Acta Odontologica Scandinavica, 1979; 37(1):15-20.

17.McDerra EJ, Pollard MA, Curzon ME. The Dental Status of Asthmatic British School Children. Pediatric Dentistry, 1998; 20(4):281-287.

18. Mehta A, Sequeira PS, Sahoo RC, Kaur G. Is Bronchial Asthma a Risk Factor for Gingival Diseases? A Control Study. The New York State Dental Journal, 2009; 75(1):44-46.

19.Stensson M, Wendt LK, Koch G, Oldaeus G, Lingström P, Birkhed D. Caries Prevalence, Caries-Related Factors and Plaque Ph in Adolescents with Long-Term Asthma. Caries Research, 2010; 44(6):540-546.

20.Ferrazzano GF, Sangianantoni G, Cantile T, Amato I, Ingenito A, Noschese P. Dental Health in Asthmatic Children: A South Italy Study. Journal of Dentistry for Children, 2012; 79(3):170-175. 